\title{
IDŐJÁRÁS
}

Quarterly Journal of the Hungarian Meteorological Service

Vol. 123, No. 1, January - March, 2019, pp. 19-38

\section{Synoptic-climatological analysis of high level air flow over the Carpathian Basin}

\author{
Anna Zsilinszki ${ }^{1}$, Zsuzsanna Dezső $^{1 *}$, Judit Bartholy ${ }^{1,2}$, and Rita Pongrácz ${ }^{1,2}$ \\ ${ }^{1}$ Department of Meteorology, Eötvös Loránd University, \\ Pázmány Péter st. 1/A, H-1117, Budapest, Hungary \\ ${ }^{2}$ Excellence Center, Faculty of Science, Eötvös Loránd University, \\ Brunszvik u. 2, H-2462, Martonvásár, Hungary
}

Corresponding authorE-mail: dezsozsuzsi@caesar.elte.hu

(Manuscript received in final form February 24, 2018)

\begin{abstract}
In recent years, several unusual (or at least very rare) weather events occurred in the Carpathian Basin, e.g., the severe snow in March 2013. We are assuming that this anomaly may be a part of the climate change-related macro-scale circulation changes, especially the changes in the characteristics of polar jetstream. For evaluating this hypothesis, we performed a detailed statistical analysis of the high level wind fields of the region for 22 vertical layers above the $500 \mathrm{hPa}$ pressure level, including the detailed analysis of average wind speed and wind directions, trend analysis of daily wind speed values, and extreme wind speed values. The results show negative trends in the mean wind speed at the higher tropospheric levels, and positive trends at the very high stratospheric levels in the Carpathian Basin. Furthermore, statistically significant trends mostly occurred in westerly winds, which is the most frequent wind direction.
\end{abstract}

Key-words: wind speed, wind direction, jet stream, frequency distribution, trend analysis

\section{Introduction}

Global climate change includes several direct and indirect consequences within the climate system. Some of these consequences are associated with regional scale climatic conditions, others are more directly linked to large-scale processes, such as atmospheric circulation regimes (e.g.,, Barnes and Polvani, 2013; Francis and Skific, 2015). Screen and Simmonds (2010) showed that the warming of the Arctic polar region is much faster than the warming of any other 
part of the world, which can be due to an Arctic amplification originating from the change in the net radiation balance causing a larger change in regional temperature compared to the global average. This is why temperature contrast between the lower and higher latitudes tends to decrease, which can result in the rearrangement of large-scale atmospheric circulation (e.g., in the behavior of the polar jet stream), and decreasing wind speeds, especially in the mid-latitudes (Francis et al., 2009).

The Arctic amplification is discussed by Hwang et al. (2011) and Screen and Simmonds (2010) in details. Specifically, sea ice loss is considered the main trigger factor to contribute to this phenomenon through several strongly interrelated positive feedbacks: (i) decreasing albedo, (ii) enhanced surface fluxes (heat and moisture fluxes are anomalously larger during the period of below normal sea ice extent), (iii) more water vapor from the open sea, (iv) higher sea surface temperatures, (v) more frequent unstable boundary layer conditions, and (vi) stronger cloud formation. As a result, more clouds lead to more downward longwave radiation, and finally, these effects together lead to warmer climatic conditions. The analysis of Francis et al. (2009) concludes that large scale atmospheric circulation patterns in the years with less sea ice tend to resemble to the circulation patterns of the negative phase of the North Atlantic Oscillation (NAO) and Arctic Oscillation (AO), because warming results in higher sea level pressure (SLP) above the North Pole affecting the storm tracks as well.

On one hand, there are lots of studies (e.g., Francis and Vavrus, 2012; Miller et al., 2010 ; Zhang et al., 2012; Knudsen et al., 2015) pointing out clear evidences of the Arctic amplification to affect atmospheric conditions and result in anomalous behavior not only in the polar region, but in the midlatitudes as well. Several analyses (Overland et al., 2012; Peings and Magnusdottir, 2014) conclude that the increasing (at least in some seasons) amplitude in Rossby waves causes their slower eastward propagation, and consequently, more persistent weather conditions in the midlatitudes. Thus, longer anomalous weather patterns can lead to extreme meteorological events. On the other hand, several studies (e.g.,, Screen and Simmonds, 2013; Barnes and Screen, 2015) emphasize the uncertainties of such overall statements.

Small changes in global circulation may lead to significant changes regionally, so in this study we focus on the region of the Carpathian Basin, by performing general statistical analysis to identify the direct or indirect effects of large scale changes in regional circulation regimes. Large scale circulation changes can be recognized more easily at higher levels than near the surface due to the negligible role of surface from the mid-troposphere upward. Therefore, this analysis covers the high level wind characteristics and trends. After introducing the data and methods (Section 2) the analysis of average wind speed and wind directions is discussed in Section 3 followed by the trend analysis of 
daily mean wind speed values, and extreme wind speed values. Finally, Section 4 summarizes the main conclusions of the paper.

\section{Data and methods}

For the present analysis we use ERA Interim Reanalysis data (Dee et al., 2011) compiled by the European Centre for Medium-Range Weather Forecast (ECMWF), for the period 1979-2015, and for 240 grid points with $0.75^{\circ}$ horizontal resolution covering Hungary and its vicinity (the geographical extent of the study domain is shown in Fig. 1). Daily 12:00 UTC wind speed and direction data of 22 levels from $500 \mathrm{hPa}$ to $1 \mathrm{hPa}$ pressure level are analyzed. The closest grid point to Budapest $\left(47.25^{\circ} \mathrm{N}, 18.75^{\circ} \mathrm{E}\right)$ is selected among the 240 grid points to represent the Carpathian Basin, and the results are shown for this representative grid point throughout this paper, where the analysis are carried out for each grid point separately.

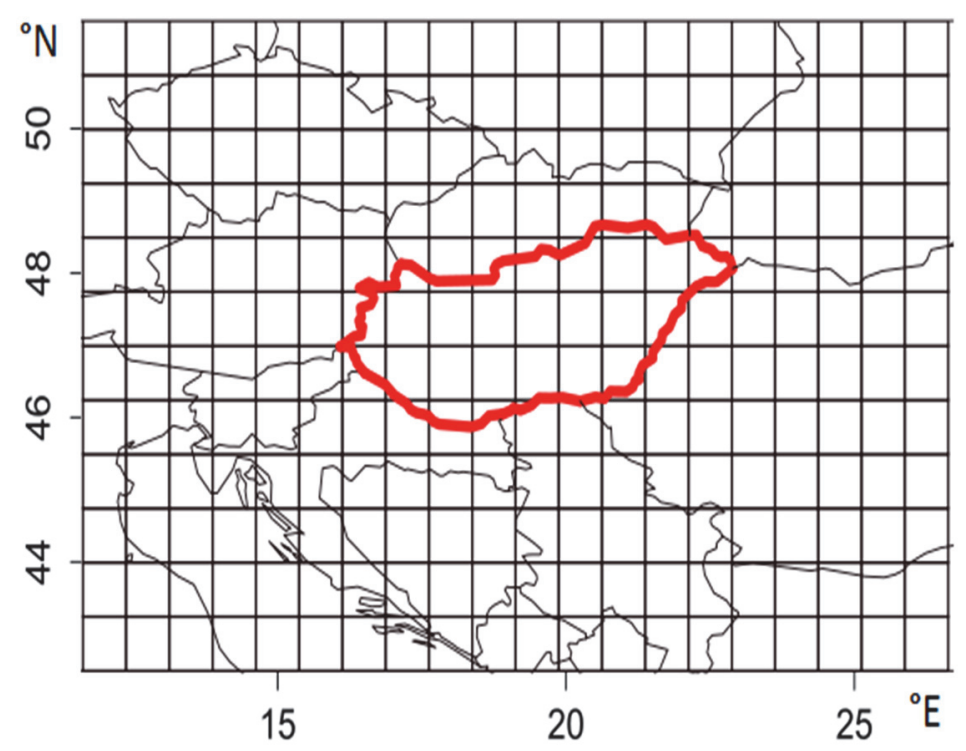

Fig. 1. The study area with $0.75^{\circ}$ horizontal resolution. Red contour indicates the country border of Hungary.

\section{Results and discussion}

Our main motivation is associated with the winter of 2012-2013 and early spring of 2013 when an anomalously large number of Mediterranean cyclones 
occurred in the Carpathian Basin (Fig. 2) resulting in significantly high amount of precipitation during this period (Vincze, 2013) compared to the usual precipitation conditions. These weather characteristics are related to a quasipermanent synoptic pattern over Europe with a south-shifted location of jet stream (Fig. 3). For the detailed analysis of the high level circulation patterns, a general statistical analysis of the high level wind fields of the region is performed for 22 vertical levels above the $500 \mathrm{hPa}$ pressure level.

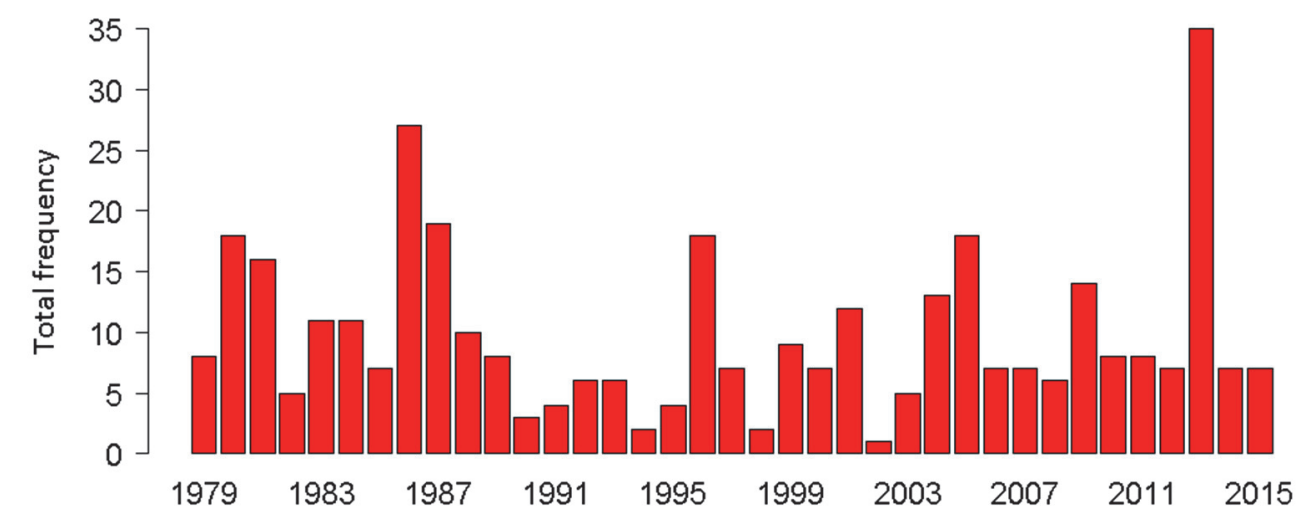

Fig. 2. The number of Mediterranean cyclones for January-February-March (JFM) in every year from 1979 to 2015 on the basis of Péczely (1961) classification types.
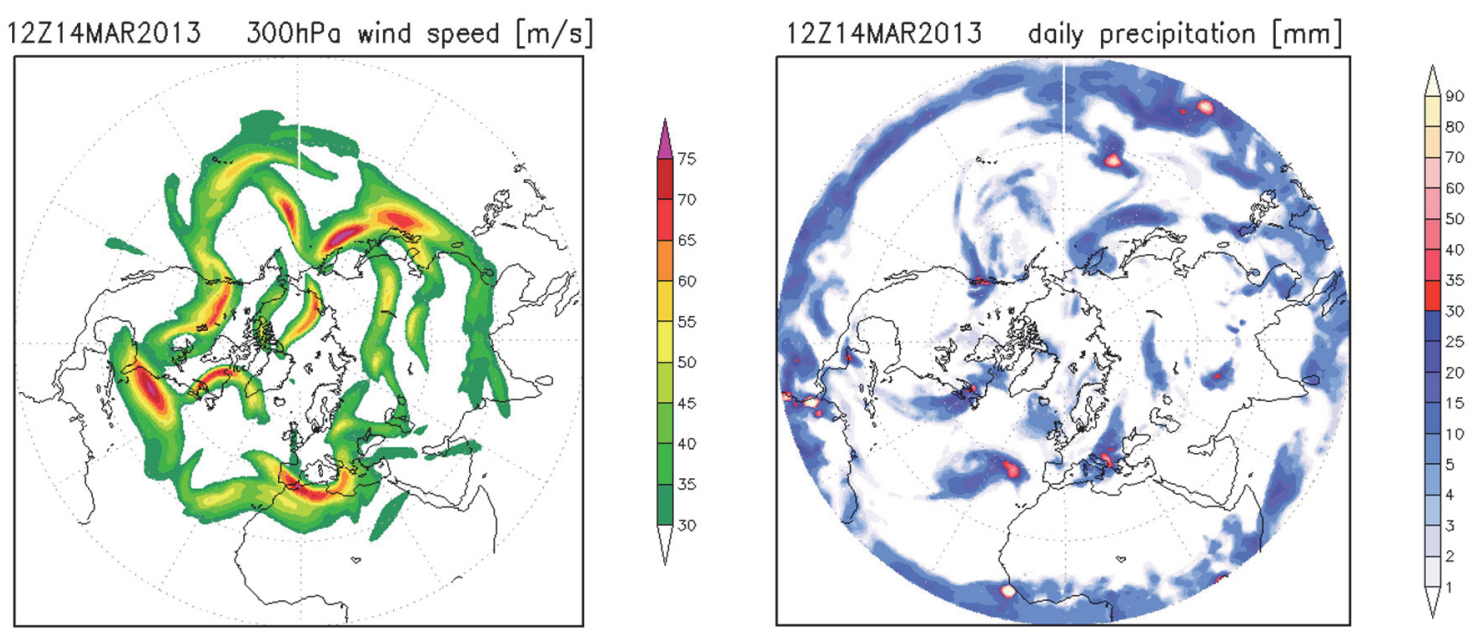

Fig. 3. Jet stream location derived from the $300 \mathrm{hPa}$ level wind field (left) and precipitation pattern (right) on March 14, 2013. 


\subsection{High level wind climatology in the Carpathian Basin}

\subsubsection{Wind speed}

As a very first statistical overview about the vertical structure of wind average, wind speed values are calculated for the target region for all the pressure levels taking into account the entire period. Fig. 4 clearly shows that the greatest mean wind speed values can be found at the $250 \mathrm{hPa}$ level within the upper troposphere. The large values of wind speed are associated with the atmospheric level where the polar jet stream is mostly located. Besides the mean, which is a very robust statistical feature of time series, the distribution of the actual values is also important, especially for meteorological variables with asymmetric distribution. Wind speed is one of these variables, and it is often modeled with Weibull distribution (e.g., Péliné et al., 2016). The empirical distribution of the $250 \mathrm{hPa}$ level wind speed values and the fitted Weibull probability density function are shown in Fig. 5. The Weibull parameters are estimated with the numerical gradient technique based on the maximum-likelihood method. For the scale and shape parameters the estimated values are 24.56 and 1.84, respectively. The most frequent wind speed values at $250 \mathrm{hPa}$ level are between $10 \mathrm{~m} / \mathrm{s}$ and $20 \mathrm{~m} / \mathrm{s}$ wind speed (the average is $22 \mathrm{~m} / \mathrm{s}$ ). A comprehensive summary of distribution can be seen in Box-Whisker plot diagram where the maximum, minimum, upper and lower quartiles, and median values are separately indicated. The Box-Whisker plot diagrams in Fig. 6 compare the distributions of the wind speed values at 18 analyzed levels. In addition to the full distribution, extreme values are especially analyzed by defining different thresholds (i.e., the median and the 99th percentile), and the Box-Whisker plot diagrams are prepared for the wind speed values above these thresholds. The intervals of wind speed range move to greater values with the height up to the $250 \mathrm{hPa}$ level, then a decrease can be recognized up to the $50 \mathrm{hPa}$ level where they start to increase again reaching the greatest values, overall, at the $1 \mathrm{hPa}$ level. 


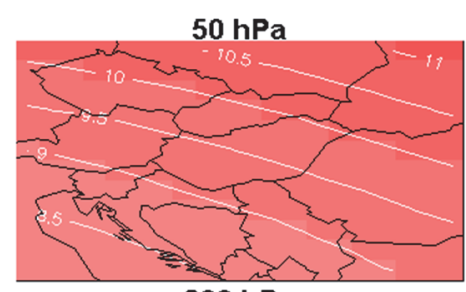

$200 \mathrm{hPa}$

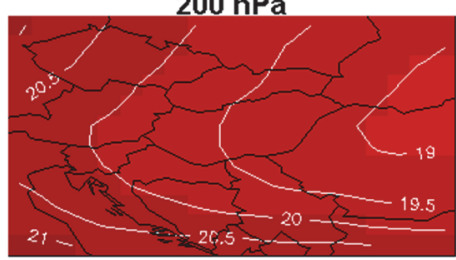

$350 \mathrm{hPa}$
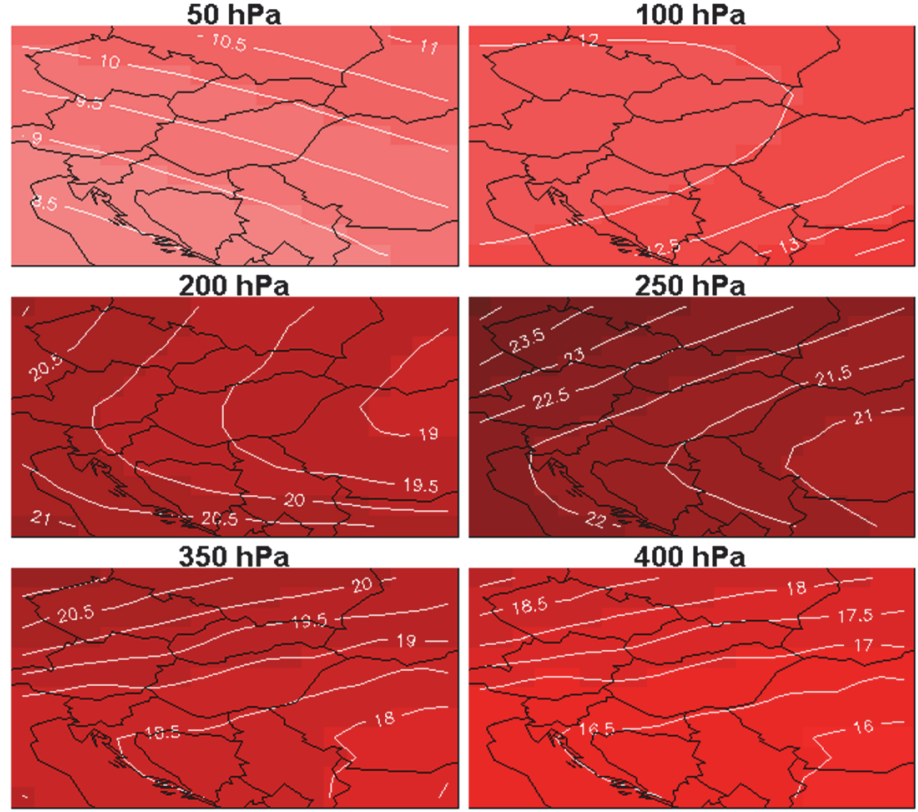

$250 \mathrm{hPa}$

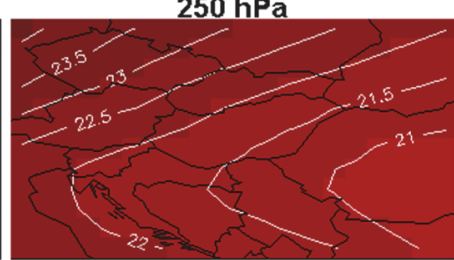

$400 \mathrm{hPa}$
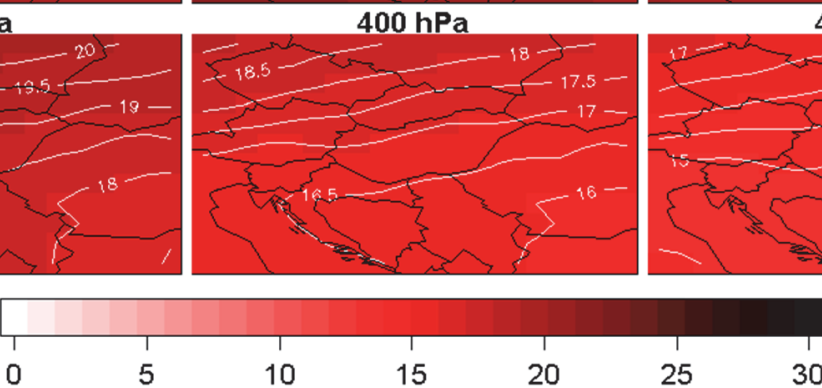

Fig. 4. Mean wind speed values $[\mathrm{m} / \mathrm{s}]$ at different levels of the upper troposphere/lower stratosphere, in the period 1979-2015.

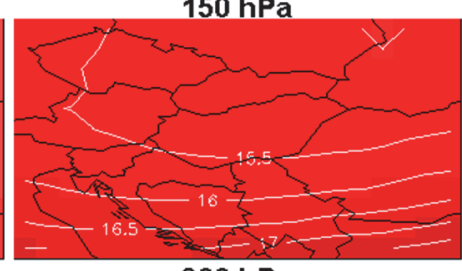

$300 \mathrm{hPa}$

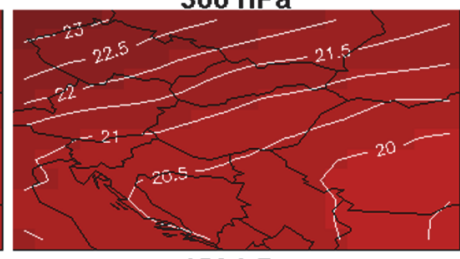

$450 \mathrm{hPa}$

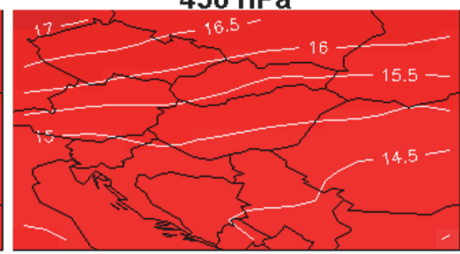

$25 \quad 30$

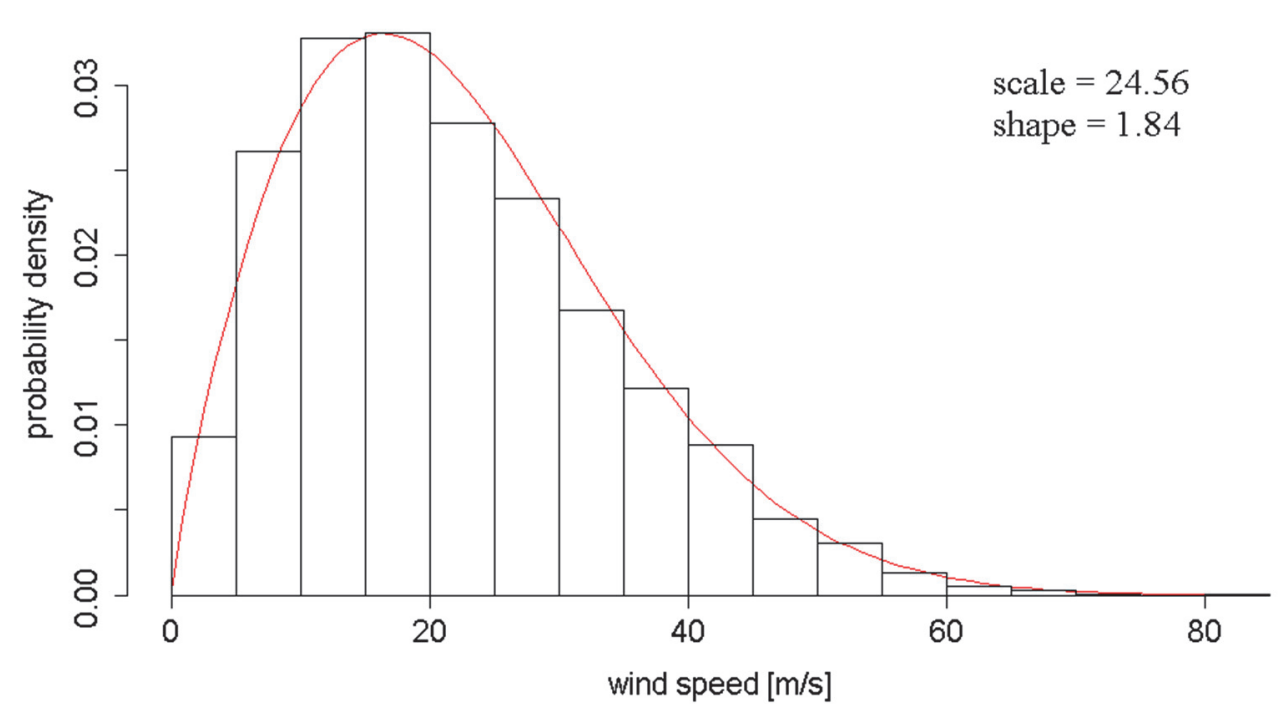

Fig. 5. Histogram of wind speed at the $250 \mathrm{hPa}$ level in the closest grid point to Budapest $\left(47.25^{\circ} \mathrm{N}, 18.75^{\circ} \mathrm{E}\right)$ and the estimated probability density function (indicated by the red curve) fitted to the empirical distribution. The scale and shape parameters of the fitted Weibull distribution are shown in the upper right corner of figure. 

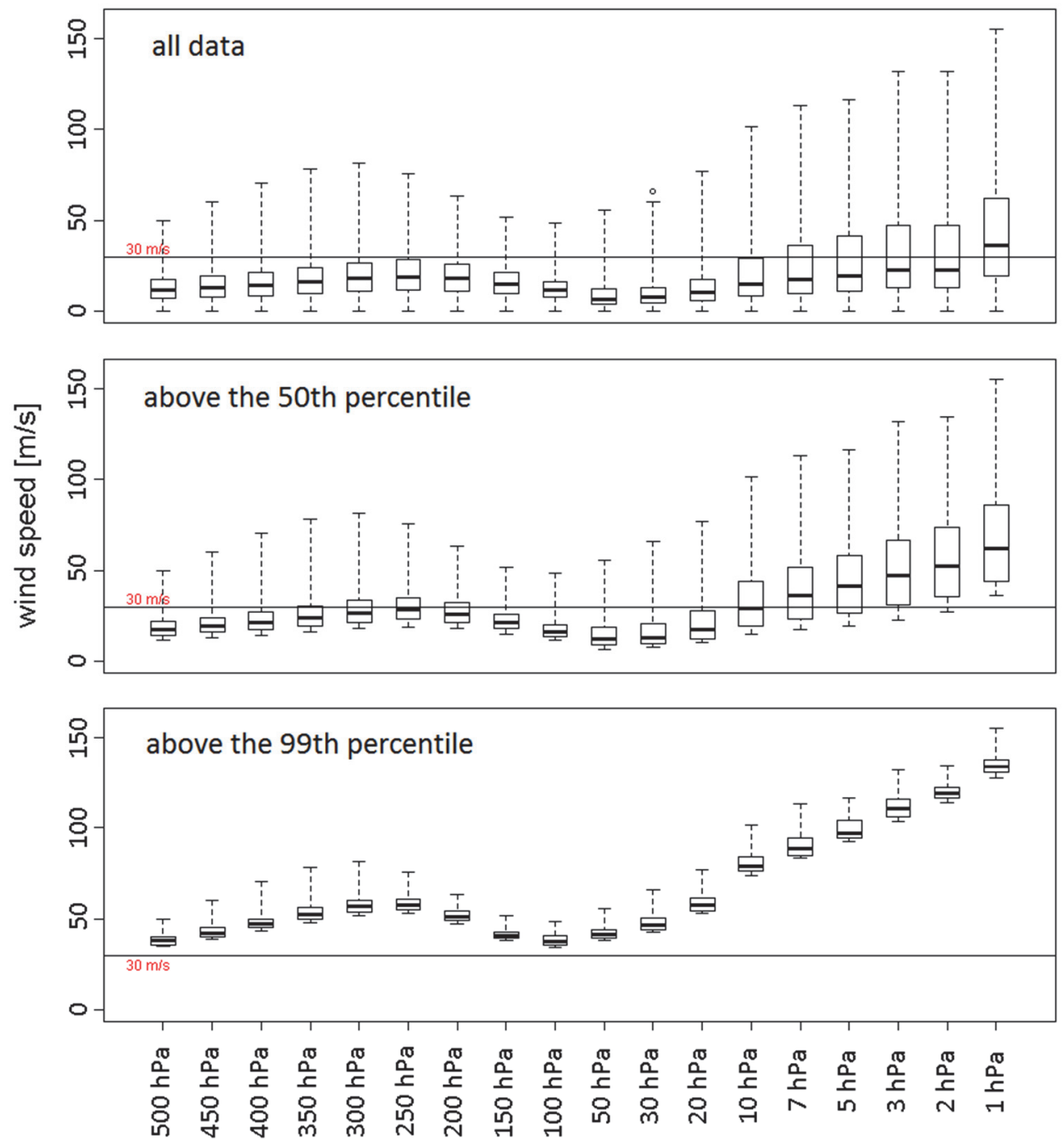

Fig. 6. Box-Whisker diagrams for wind speed distribution for the whole time series (top), wind speed values above the 50th percentile, i.e., median (middle), and the 99th percentile (bottom) in the closest grid point to Budapest $\left(47.25^{\circ} \mathrm{N}, 18.75^{\circ} \mathrm{E}\right), 1979$ 2015. Dashed vertical lines indicate the ranges between the minimum and maximum wind speed, boxes are drawn between the lower and upper quartiles, and the medians are indicated by the thicker horizontal lines within the boxes. The long horizontal line highlights the wind speed value of $30 \mathrm{~m} / \mathrm{s}$ (which is the threshold value commonly used for jet stream identification).

\subsubsection{Wind direction}

37-year daily averages of wind speed and direction are plotted together to represent the annual cycle of long-term mean wind at different levels. Figs. 7 and 8 show the results for the $250 \mathrm{hPa}$ and $50 \mathrm{hPa}$ level, respectively. The mean wind directions were calculated with the method discussed by Grange (2014), i.e., by the arcus tangent function of mean wind components. Only a very weak 
annual cycle can be recognized in both the wind directions and wind speed values at the $250 \mathrm{hPa}$ level (Fig, 7). Above the $70 \mathrm{hPa}$ level, a substantial annual cycle is clearly visible at the stratospheric levels (Fig. 8).

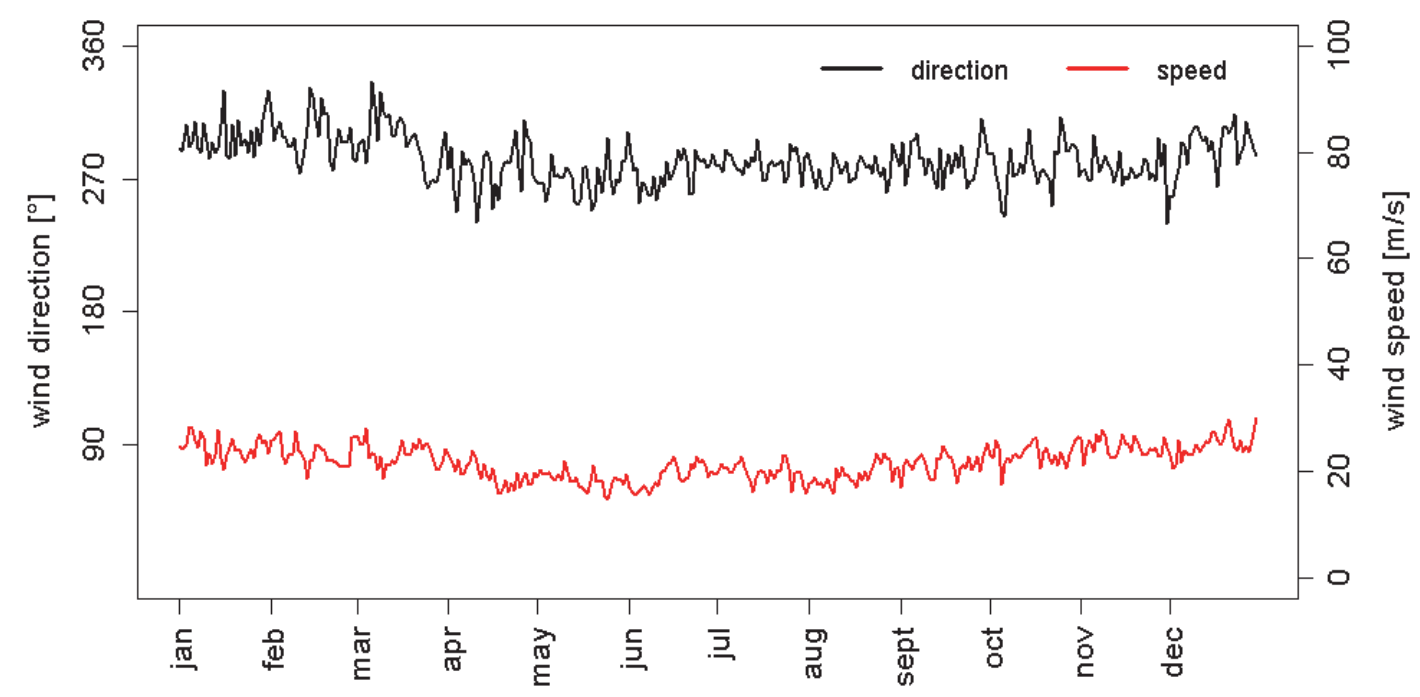

Fig. 7. Annual average wind direction $\left[^{\circ}\right]$ and wind speed $[\mathrm{m} / \mathrm{s}]$ at the $250 \mathrm{hPa}$ level in the closest grid point to Budapest $\left(47.25^{\circ} \mathrm{N}, 18.75^{\circ} \mathrm{E}\right)$, in the period $1979-2015$.

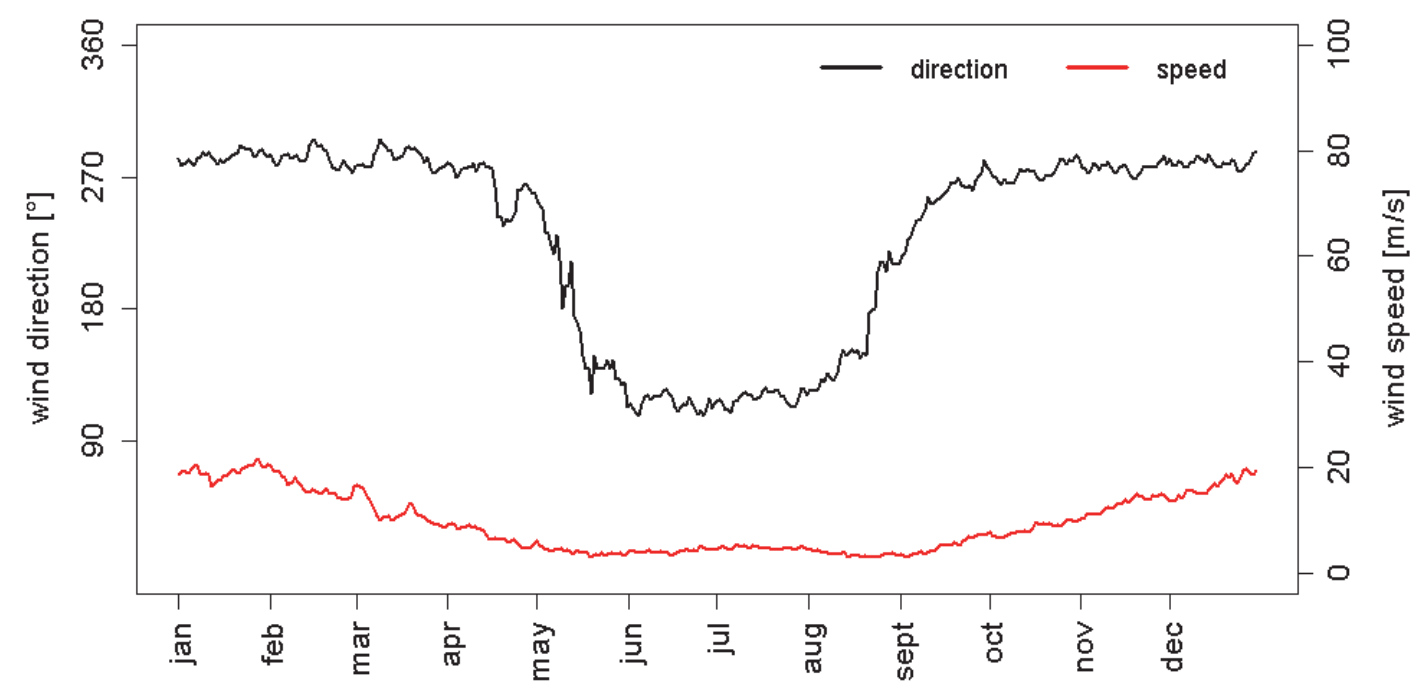

Fig. 8. Annual average wind direction $\left[^{\circ}\right]$ and wind speed $[\mathrm{m} / \mathrm{s}]$ at the $50 \mathrm{hPa}$ level in the closest grid point to Budapest $\left(47.25^{\circ} \mathrm{N}, 18.75^{\circ} \mathrm{E}\right)$, in the period $1979-2015$. 
Besides the overall means, the annual cycle can be analyzed in more details when the actual time series are plotted for the entire period of 1979-2015. For this purpose, directions are divided into two main groups, westerly wind (between $180^{\circ}$ and $360^{\circ}$ ) and easterly wind (between $0^{\circ}$ and $180^{\circ}$ ). The full time series are shown for five selected levels, $10 \mathrm{hPa}, 50 \mathrm{hPa}, 150 \mathrm{hPa}, 250 \mathrm{hPa}$, and $500 \mathrm{hPa}$ (Fig. 9). At the higher levels (between $1 \mathrm{hPa}$ and $70 \mathrm{hPa}$ ), the wind turns from westerly to easterly direction, and the wind speed becomes weaker around early May, and then, it turns back to westerly in late August, early September (Fig. 9). At the lower levels (from $100 \mathrm{hPa}$ down to $500 \mathrm{hPa}$ ), this annual periodicity disappears, and easterlies become less frequent (below 25\%) overall. The least frequency occurrence of easterlies can be detected at the 150 $\mathrm{hPa}$ level, where it is only $10 \%$ for the entire 37 years.

The total ratio of the westerly (W) and easterly (E) winds are shown above the upper right corners of the diagrams for each level.

For further analysis, the annual cycle of the relative frequency distributions of wind directions at each level is determined using four main classes (i.e., N: above $315^{\circ}$ or below $45^{\circ}$, E: $45^{\circ}-135^{\circ}$, S: $135^{\circ}-225^{\circ}$, and $\mathrm{W}: 225^{\circ}-315^{\circ}$ ). Fig. 10 shows that below the $100 \mathrm{hPa}$ level, class $\mathrm{W}$ is clearly the dominant wind direction with about $50 \%$ occurrence. Class $\mathrm{N}, \mathrm{S}$, and $\mathrm{E}$ occurred with an average $25 \%, 15 \%$, and $10 \%$ relative frequency, respectively, at the $250 \mathrm{hPa}$ level, and no significant annual cycle can be identified. Substantially different results with a clear annual cycle can be recognized above $100 \mathrm{hPa}$. The $50 \mathrm{hPa}$ level is shown among these high levels in Fig. 11. It can be seen that class W is still the most dominant wind direction on annual average $(53 \%$ is the overall relative frequency), but the distribution changes throughout the year: $70-75 \%$ from October to mid-April, then decreases to $<1 \%$ by July, and starts to increase again in August. The annual mean relative frequency of class $\mathrm{N}$ at the $50 \mathrm{hPa}$ level is $12 \%$ - about the half of the relative frequency of class $\mathrm{N}$ at the $250 \mathrm{hPa}$ level, which is due to the dominant occurrence of class E above $100 \mathrm{hPa}$ in summer when both class $\mathrm{W}$ and class $\mathrm{N}$ disappear from the distribution. The relative frequency of class $\mathrm{S}$ also increases during April-May, reaches its maximum in June-July ( $25 \%)$, and decreases in August-September together with class E. Overall, the annual mean relative frequency of class $\mathrm{S}$ and class $\mathrm{E}$ at the $50 \mathrm{hPa}$ level is $15 \%$ and $20 \%$, respectively. The dominant occurrence of class $\mathrm{E}$ in summer results in becoming the second most often appearing direction at this high level with the maximum relative frequency reaching $75 \%$ in July. 


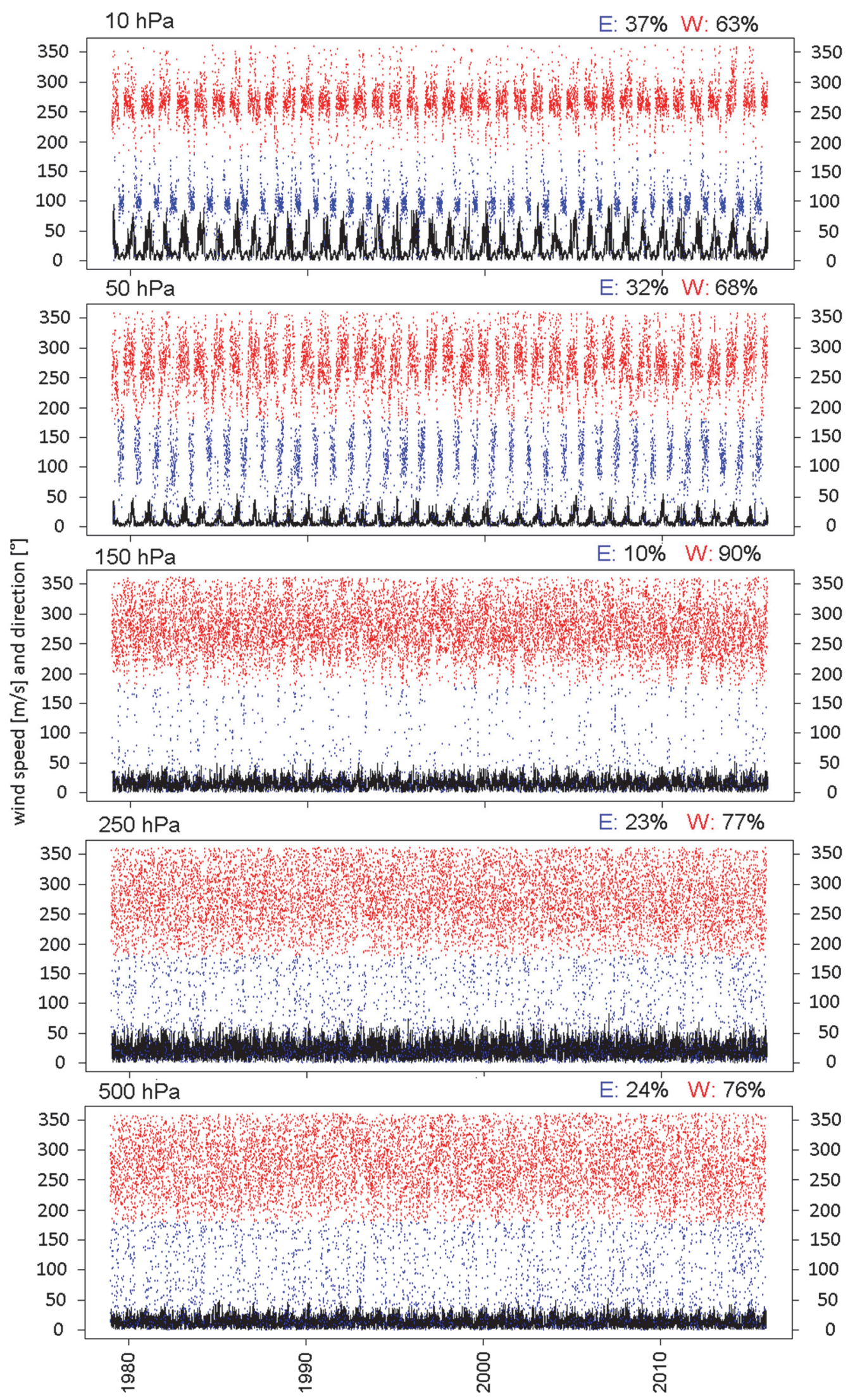

Fig. 9. Time series of wind speed (black lines) and directions (blue dots - easterly directions, red dots - westerly directions) at the closest grid point to Budapest $\left(47.25^{\circ} \mathrm{N}\right.$, $18.75^{\circ} \mathrm{E}$ ), in the period $1979-2015$. 


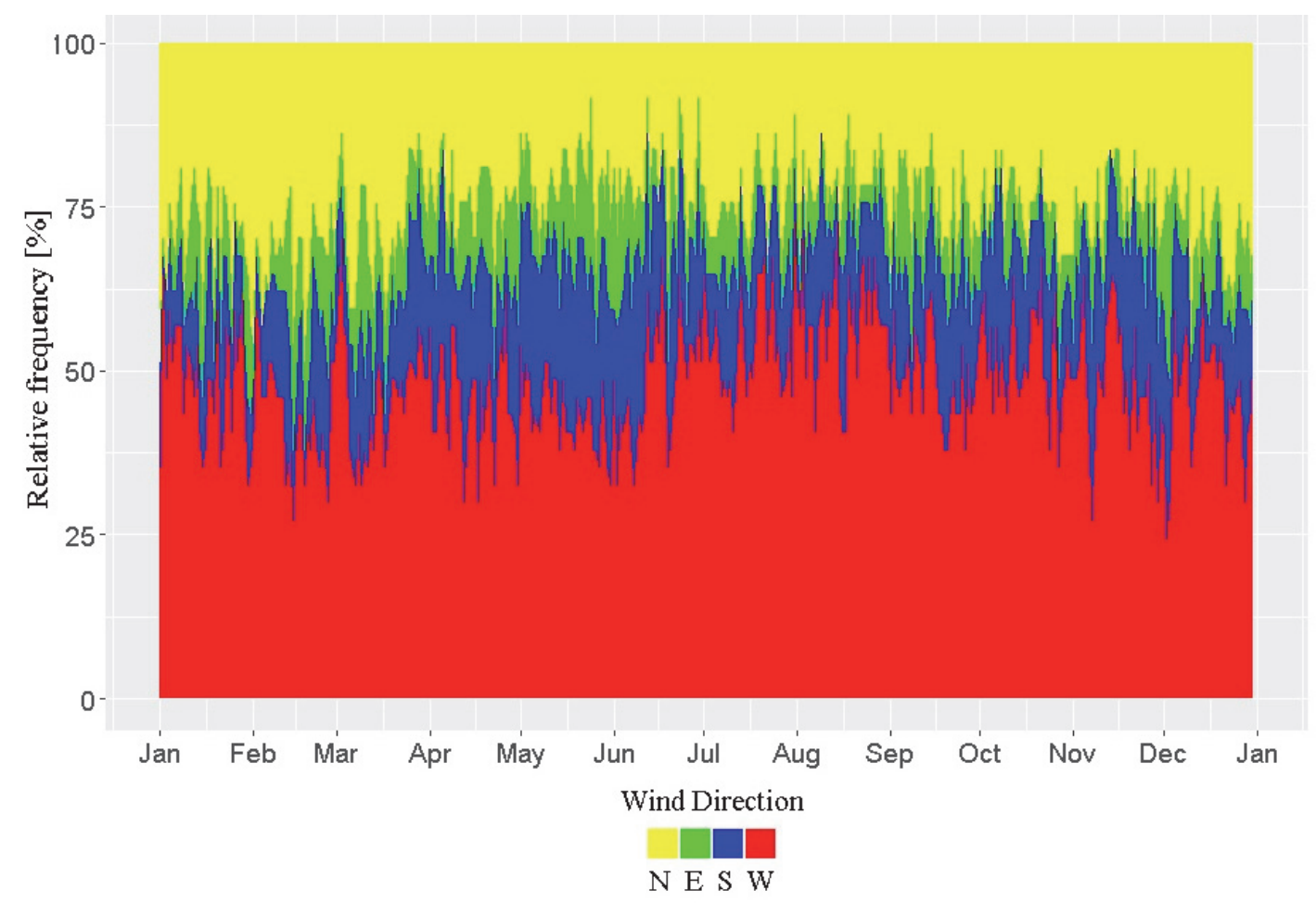

Fig. 10. Annual relative frequency of wind direction classes at the $250 \mathrm{hPa}$ level in the closest grid point to Budapest $\left(47.25^{\circ} \mathrm{N}, 18.75^{\circ} \mathrm{E}\right)$, in the period $1979-2015$.

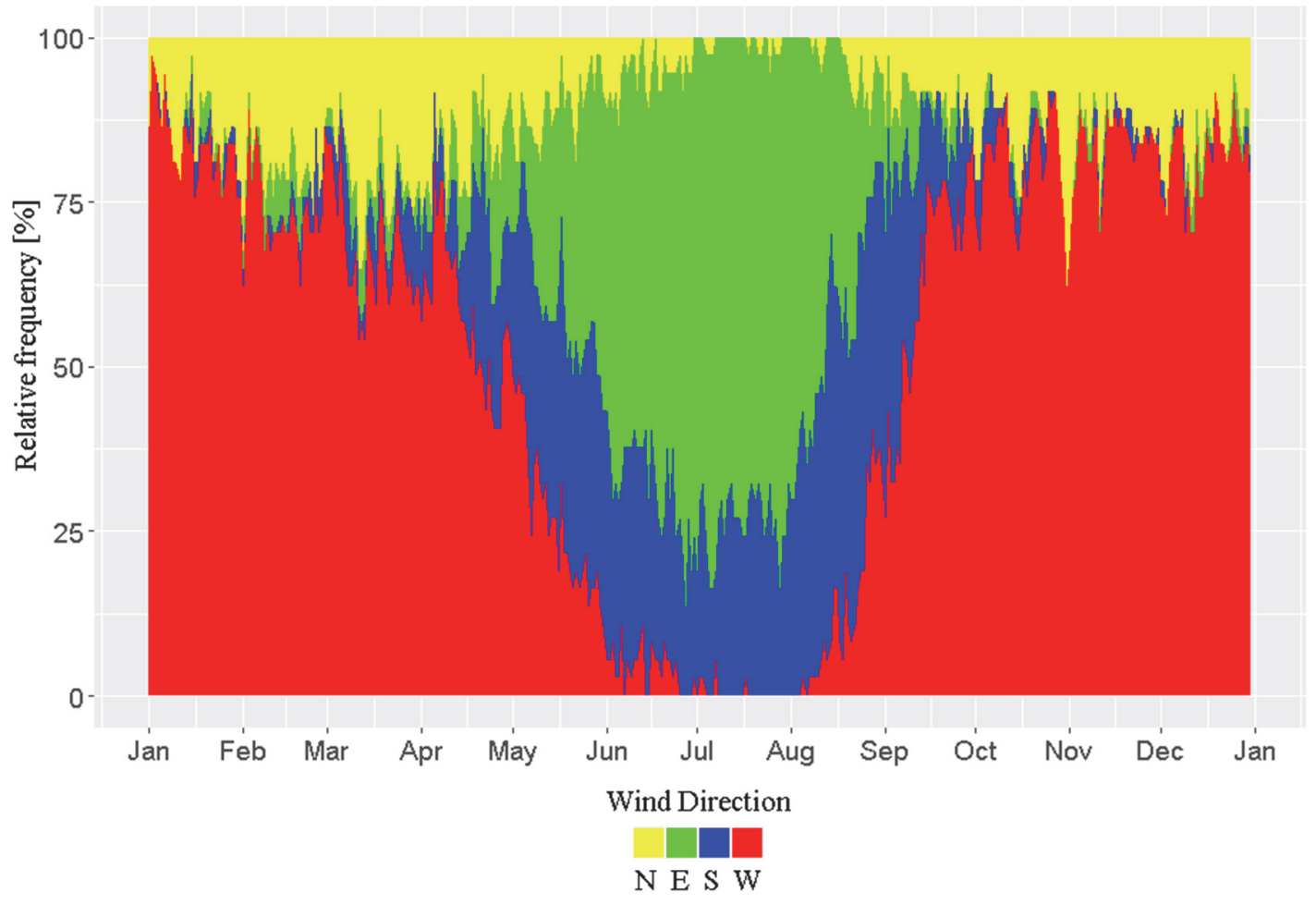

Fig. 11. Annual relative frequency of wind direction classes at the $50 \mathrm{hPa}$ level in the closest grid point to Budapest $\left(47.25^{\circ} \mathrm{N}, 18.75^{\circ} \mathrm{E}\right)$, in the period $1979-2015$. 
In order to analyze the distribution of wind direction in more details throughout the year, wind roses were determined on a monthly scale for every level. The wind roses indicate the total frequency in a given direction using 8 different subclasses of directions (Table 1) and the corresponding wind speed distributions.

Table 1. Defined subclasses of wind direction used in wind roses

\begin{tabular}{cc}
\hline \hline subclass & interval \\
\hline \hline $\mathrm{N}$ & $>337.5^{\circ}$, or $<22.5^{\circ}$ \\
$\mathrm{NE}$ & $22.5^{\circ}-67.5^{\circ}$ \\
$\mathrm{E}$ & $67.5^{\circ}-112.5^{\circ}$ \\
$\mathrm{SE}$ & $112.5^{\circ}-157.5^{\circ}$ \\
$\mathrm{S}$ & $157.5^{\circ}-202.5^{\circ}$ \\
$\mathrm{SW}$ & $202.5^{\circ}-247.5^{\circ}$ \\
$\mathrm{W}$ & $247.5^{\circ}-292.5^{\circ}$ \\
$\mathrm{NW}$ & $292.5^{\circ}-337.5^{\circ}$ \\
\hline
\end{tabular}

Table 2 compares the total occurrences and relative frequencies of the subclasses at the two selected levels (i.e., $250 \mathrm{hPa}$ and $50 \mathrm{hPa}$ ). In overall agreement with previous results shown in Figs. 7-11, subclass $\mathrm{W}$ is dominant at every level in the most part of the year. As an example, the monthly distributions at the $250 \mathrm{hPa}$ level are shown in Fig. 12, since this is the general level of the polar jet in the region. At this level, $26 \%$ of the total data are in subclass $\mathrm{W}$, and together with the adjacent subclasses (i.e., NW, SW) the relative frequency is $65 \%$, while easterly subclasses (NE, E, SE) together add up to only $15 \%$ leaving $13 \%$ and $7 \%$ in subclasses $\mathrm{N}$ and $\mathrm{S}$, respectively. At a monthly resolution, a small fluctuation can be seen in the frequency of direction subclasses during the year. 
Table 2. Distribution of wind direction subclasses at $250 \mathrm{hPa}$ (left) and $50 \mathrm{hPa}$ (right), in the period 1979-2015, in the closest grid point to Budapest $\left(47.25^{\circ} \mathrm{N}, 18.75^{\circ} \mathrm{E}\right)$. The most frequent subclass is highlighted by bold numbers

\begin{tabular}{ccccc}
\hline \hline \multirow{2}{*}{ subclass } & \multicolumn{2}{c}{$\mathbf{2 5 0}$ hPa level } & \multicolumn{2}{c}{$\mathbf{5 0 ~ h P a ~ l e v e l ~}$} \\
\cline { 2 - 5 } & $\begin{array}{c}\text { total } \\
\text { frequency }\end{array}$ & $\begin{array}{c}\text { relative } \\
\text { frequency }\end{array}$ & $\begin{array}{c}\text { total } \\
\text { frequency }\end{array}$ & $\begin{array}{c}\text { relative } \\
\text { frequency }\end{array}$ \\
\hline \hline $\mathrm{N}$ & 1722 & $13 \%$ & 655 & $5 \%$ \\
$\mathrm{NE}$ & 883 & $7 \%$ & 420 & $3 \%$ \\
$\mathrm{E}$ & 525 & $4 \%$ & 1376 & $10 \%$ \\
$\mathrm{SE}$ & 549 & $4 \%$ & 1777 & $13 \%$ \\
$\mathrm{~S}$ & 998 & $7 \%$ & 812 & $6 \%$ \\
$\mathrm{SW}$ & 2491 & $18 \%$ & 1565 & $12 \%$ \\
$\mathrm{~W}$ & $\mathbf{3 5 4 7}$ & $\mathbf{2 6 \%}$ & $\mathbf{4 5 1 6}$ & $\mathbf{3 3 \%}$ \\
$\mathrm{NW}$ & 2799 & $21 \%$ & 2393 & $18 \%$ \\
\hline
\end{tabular}

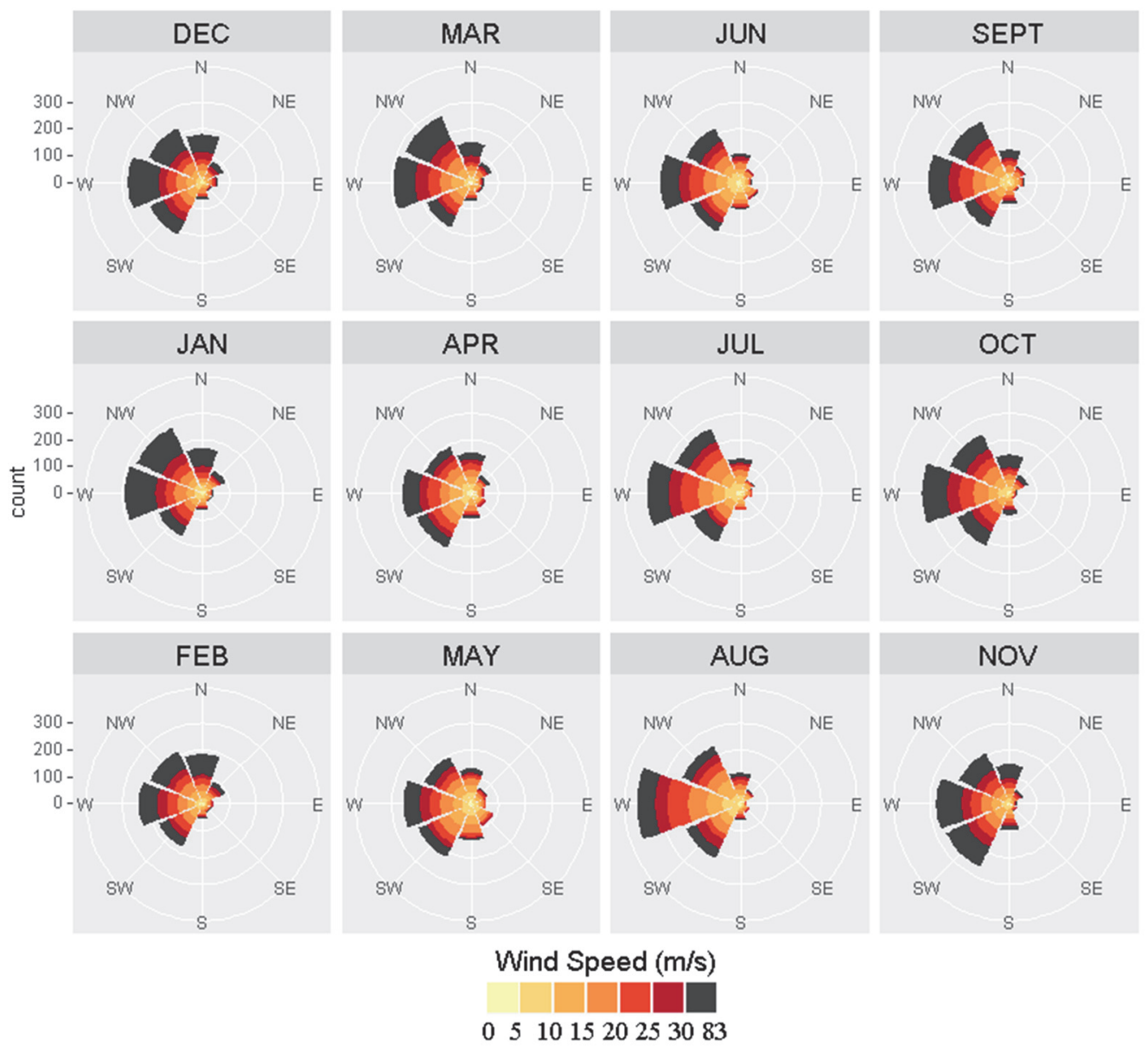

Fig. 12. Monthly distribution of wind direction subclasses at the $250 \mathrm{hPa}$ level, the radius of an individual graph indicates the frequency, colors indicate the distribution of wind speed values within the direction subclasses. The total number of cases is 13149 (the number of wind calm conditions, i.e., below $0.1 \mathrm{~m} / \mathrm{s}$ is 2 ) in the closest grid point to Budapest $\left(47.25^{\circ} \mathrm{N}, 18.75^{\circ} \mathrm{E}\right)$, in the period $1979-2015$. 


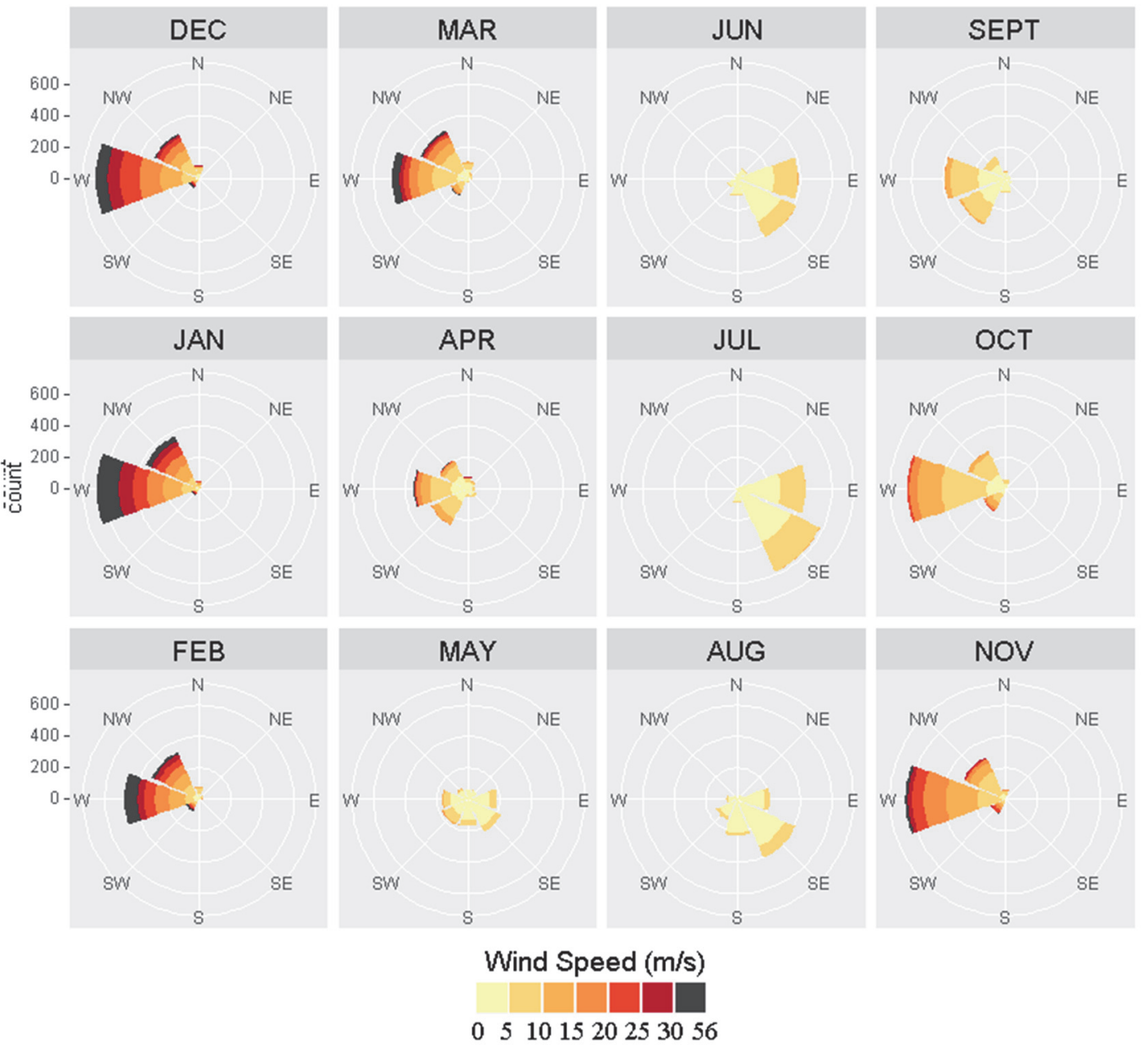

Fig. 13. Monthly distribution of wind direction subclasses at the $50 \mathrm{hPa}$ level, the radius of an individual graph indicates the frequency, colors indicate the distribution of wind speed values within the direction subclasses. The total number of cases is 13149 (the number of wind calm conditions, i.e., below $0.1 \mathrm{~m} / \mathrm{s}$ is 5 ), in the closest grid point to Budapest $\left(47.25^{\circ} \mathrm{N}, 18.75^{\circ} \mathrm{E}\right)$, in the period $1979-2015$.

Then, in the higher atmospheric levels, subclasses $\mathrm{E}$ and SE occur more frequently during summer with weaker wind speed values (e.g., at the $50 \mathrm{hPa}$ level as shown in Fig. 13). Consequently, the annual frequency of easterly winds (subclasses NE, E, SE) add up to $26 \%$ at the $50 \mathrm{hPa}$ level, which is about 1.5 times of the combined frequency of these at the $250 \mathrm{hPa}$ level. Despite this increased frequency, westerlies (i.e., subclasses NW, W, SW) are still dominant on annual scale with $63 \%$ altogether. Finally, the meridional subclasses (N, S) almost disappear, with a relative frequency of $5 \%$ and $6 \%$, respectively. Similar conclusions can be drawn at the high levels above $50 \mathrm{hPa}$. 


\subsection{Linear trend analysis}

After the detailed frequency distribution analysis, we focused on the potentially systematic changes of wind by fitting linear trends to the entire database of wind time series (1979-2015) for the Carpathian Basin using the linear regression function, $y=a \cdot x+b$. First, annual mean wind speeds (calculated from the daily data of 12 UTC) are analyzed. The fitted linear trend coefficients (Fig. 14) are significant (at the $\mathrm{p}=0.05$ level of significance) at very high levels, i.e., from $3 \mathrm{hPa}$ upward (increasing trend) and at the tropospheric levels between $300 \mathrm{hPa}$ and $500 \mathrm{hPa}$ (decreasing trend). Besides the annual mean wind speed time series, the annual occurrences of strong wind, i.e., wind speed values above 30 $\mathrm{m} / \mathrm{s}$, are also analyzed (Fig. 15). In this case, statistically significant increasing and decreasing trends can be identified above the $5 \mathrm{hPa}$ level and at the $350 \mathrm{hPa}$ level, respectively.

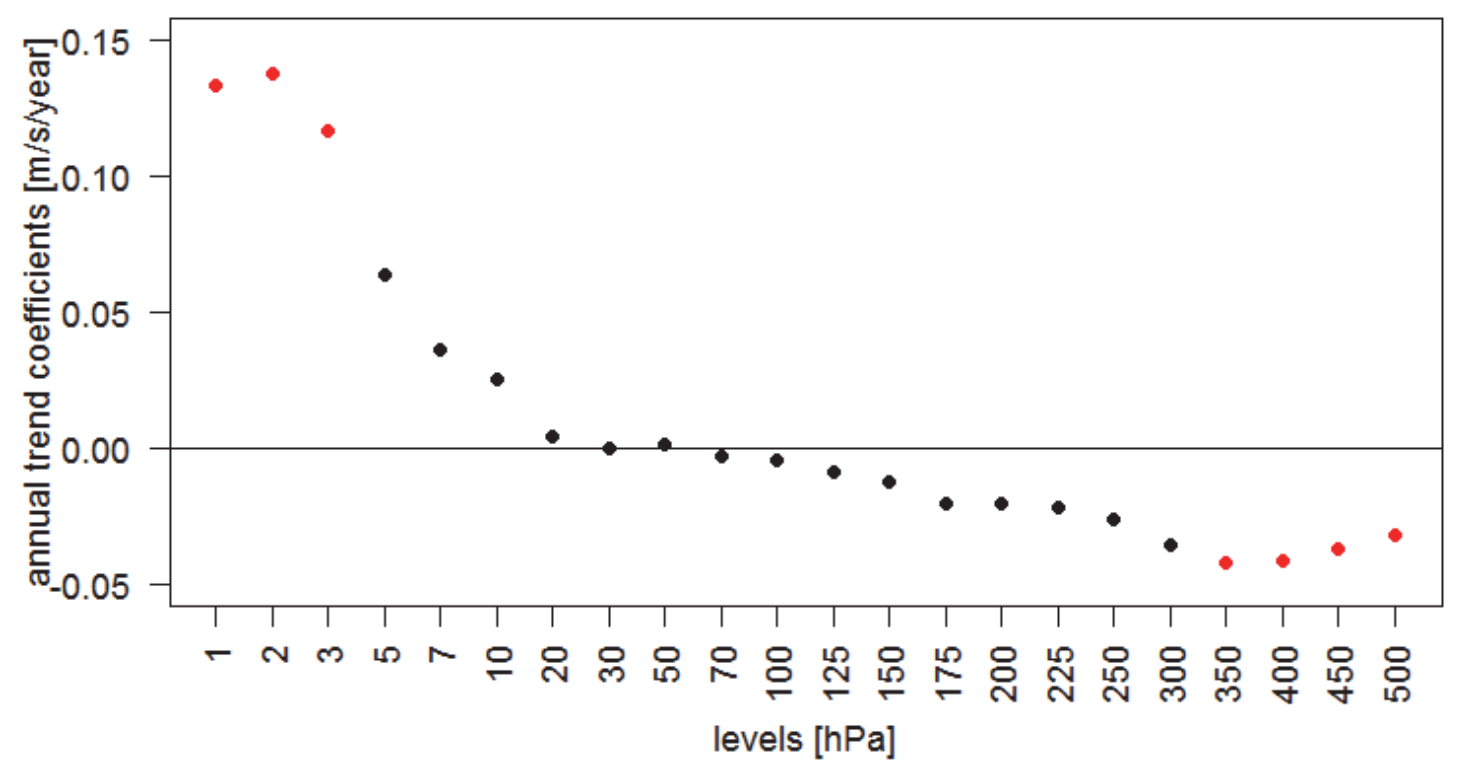

Fig. 14. Trend coefficients (steepness) of linear regression fitted to the annual mean wind time series for all the analyzed levels, for the period 1979-2015, in the closest grid point to Budapest $\left(47.25^{\circ} \mathrm{N}, 18.75^{\circ} \mathrm{E}\right)$. Red symbols indicate the statistically significant $(p=0.05)$ coefficient values. 


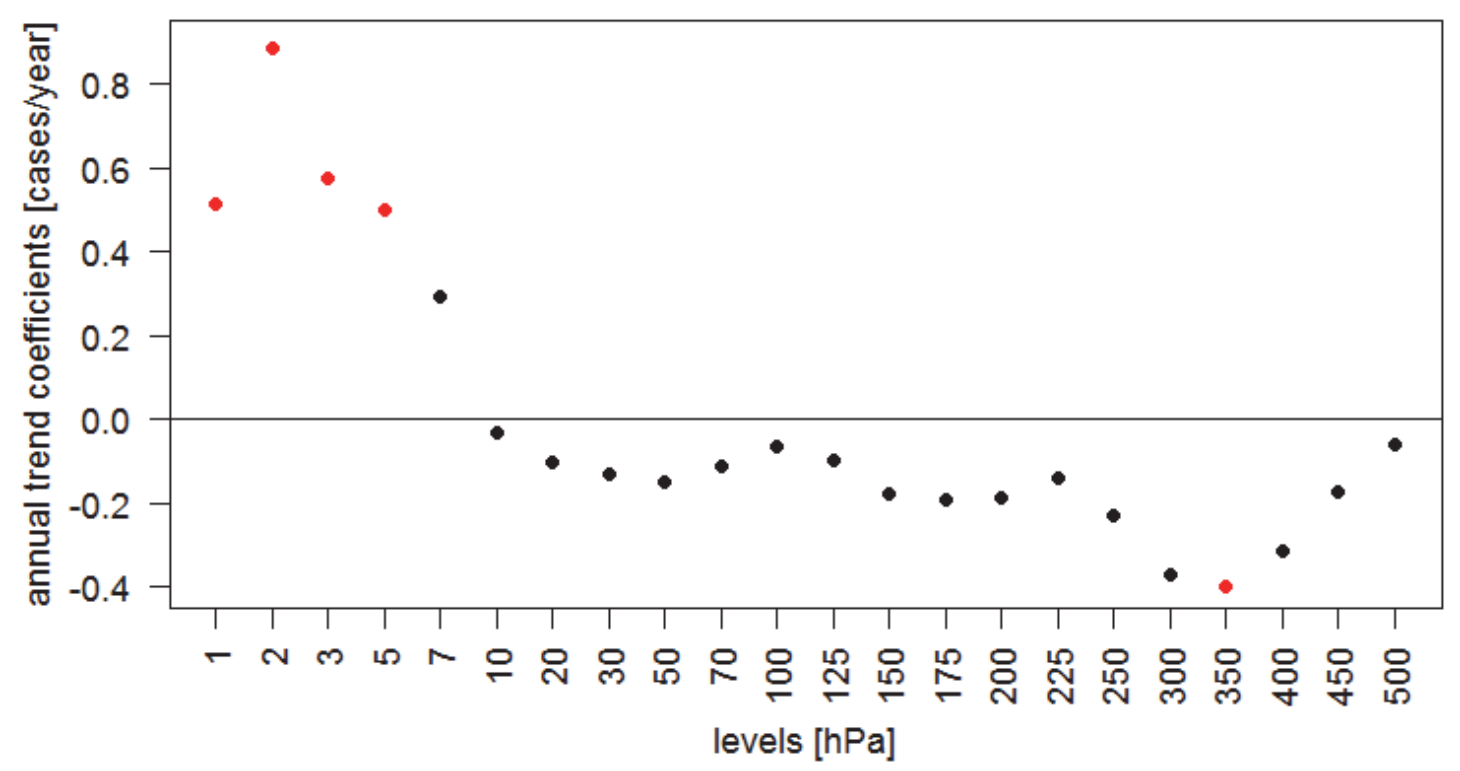

Fig. 15. Trend coefficients (steepness) of linear regression fitted to the annual frequency of wind speed above $30 \mathrm{~m} / \mathrm{s}$ for all the analyzed levels, for the period 1979-2015, in the closest grid point to Budapest $\left(47.25^{\circ} \mathrm{N}, 18.75^{\circ} \mathrm{E}\right)$. Red symbols indicate the statistically significant coefficient values.

The dataset of the $250 \mathrm{hPa}$ level wind speed is divided into two parts (i.e., 1979-1997 and 1997-2015), and trend analysis is carried out on them separately. The fitted linear regression trend coefficients for the second period (1997-2015) are negative: $-0.14 \mathrm{~m} / \mathrm{s} /$ year and -1.12 cases/year for the annual mean wind speed and the annual frequency of wind speed above $30 \mathrm{~m} / \mathrm{s}$, respectively. According to the Mann-Kendall significance test, the corresponding $p$-values are 0.032 and 0.014 , which show statistically significant decrease in the past few decades.

The trend analysis is also completed by the four wind direction classes $(\mathrm{N}$, $\mathrm{E}, \mathrm{S}$, and $\mathrm{W}$ ) both for the annual means and the annual frequencies of cases with wind speed above $30 \mathrm{~m} / \mathrm{s}$. The fitted linear regressions are shown in Fig. 16 for the $250 \mathrm{hPa}$ and $500 \mathrm{hPa}$ levels. 
NORTHERLY WINDS $\left(315^{\circ}-45^{\circ}\right)$
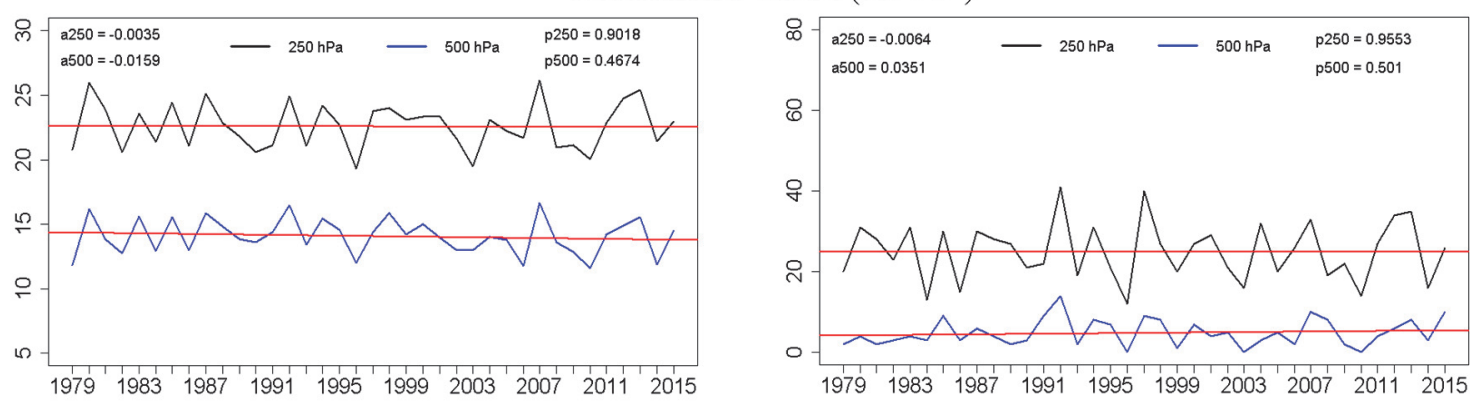

EASTERLY WINDS $\left(45^{\circ}-135^{\circ}\right)$
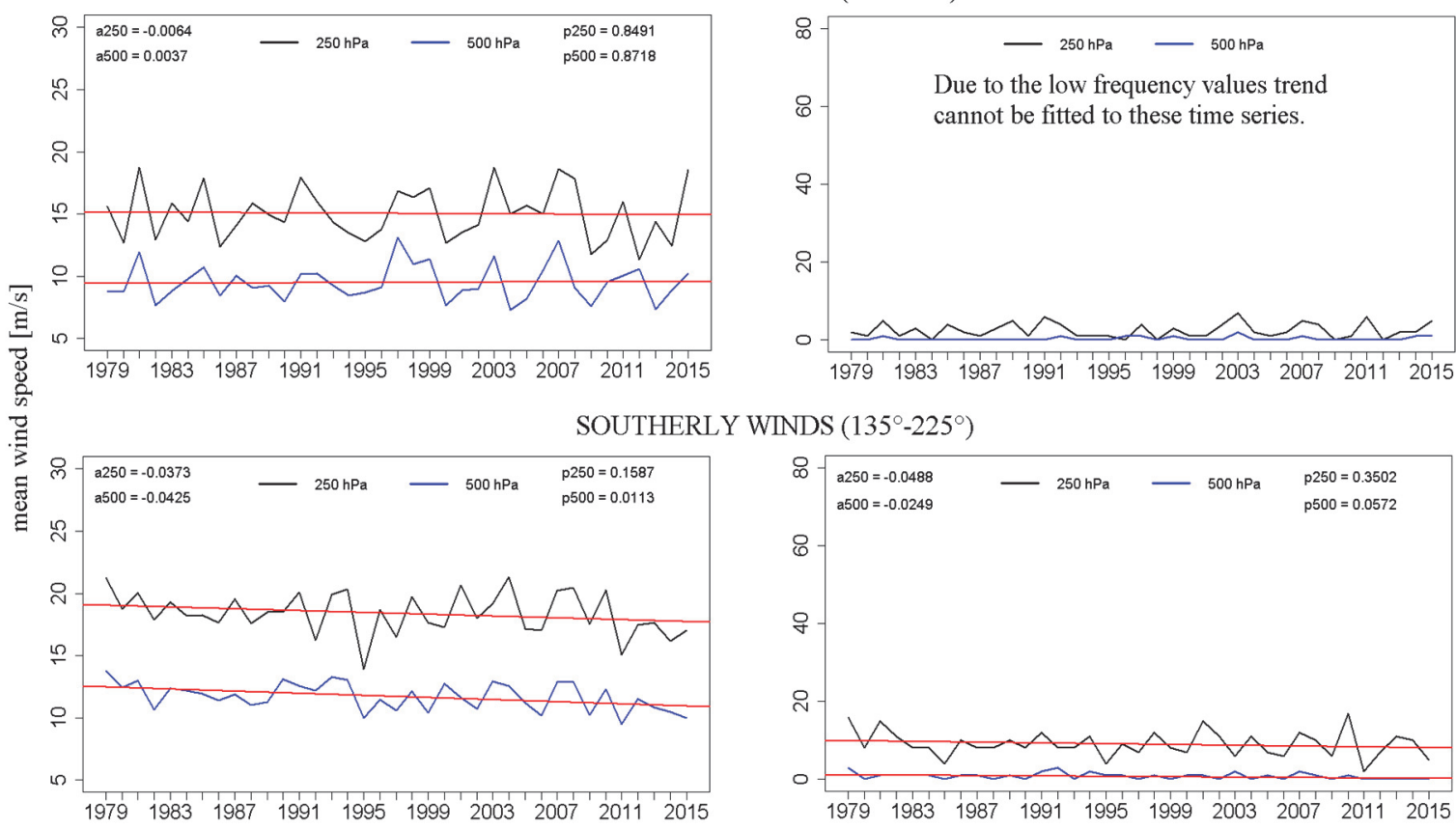

$\operatorname{DS}\left(135^{\circ}-225^{\circ}\right)$

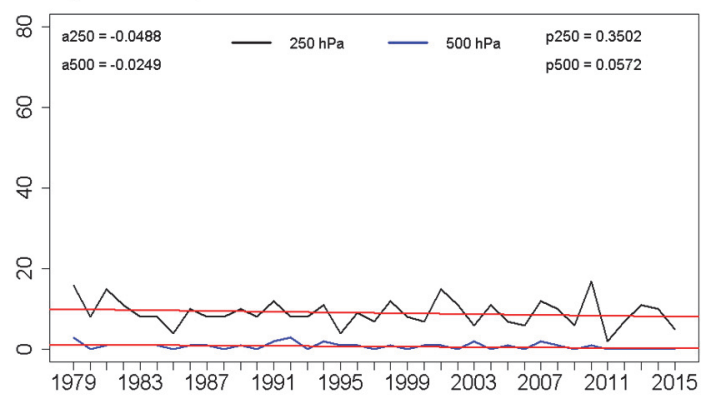

WESTERLY WINDS $\left(225^{\circ}-315^{\circ}\right)$
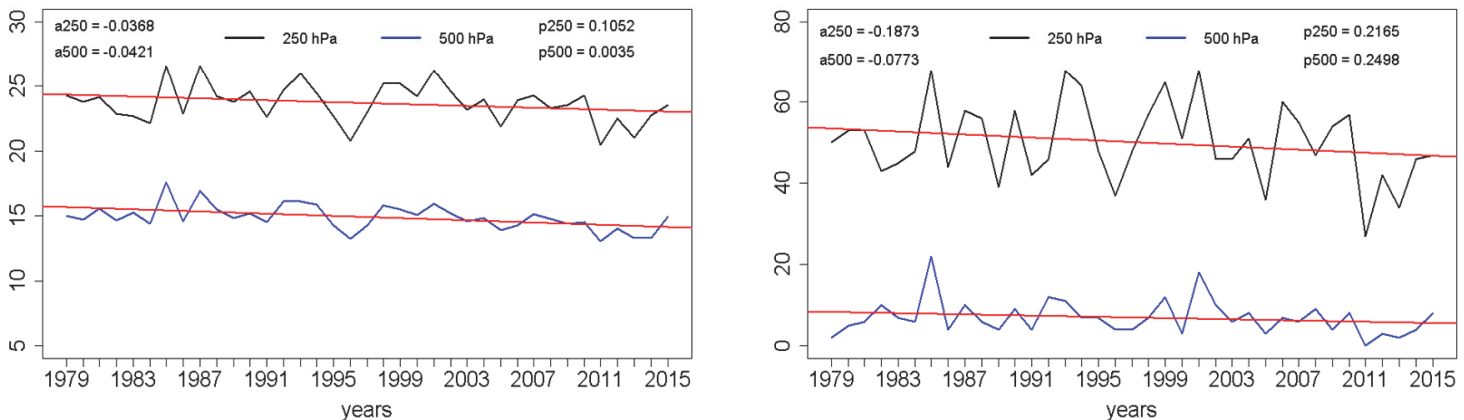

Fig. 16. Summary of the linear trend analysis of high level winds by the main wind direction classes at the $250 \mathrm{hPa}$ (black line) and $500 \mathrm{hPa}$ (blue line) levels at Budapest for the annual mean wind speed (left) and the annual number of cases with strong wind speed $(>30 \mathrm{~m} / \mathrm{s})$ (right). The steepness of the fitted trend lines are shown as a250 (expressed in $\mathrm{m} / \mathrm{s} /$ year) and a500 (expressed in case/year), respectively. Furthermore, the corresponding $\mathrm{p}$-values are also shown as p250 and p500, respectively. 
The conclusions from all the 22 analyzed levels are summarized by the wind direction classes for the annual means as follows. (1) Slight decrease (negative trend coefficient) can be seen in the annual means of northerly winds in 18 levels out of the total 22 analyzed levels, but none of them is statistically significant. (2) The trend coefficients of the annual mean easterly winds are mostly positive (from $1 \mathrm{hPa}$ to $225 \mathrm{hPa}$ ), which are significant only at the very high stratospheric levels: the $2 \mathrm{hPa}, 3 \mathrm{hPa}, 5 \mathrm{hPa}, 20 \mathrm{hPa}, 30 \mathrm{hPa}$, and $50 \mathrm{hPa}$ levels. The fitted linear trend coefficients turns to negative at the tropospheric levels (from $250 \mathrm{hPa}$ down to $500 \mathrm{hPa}$ levels), but none of them is significant according to the Mann-Kendall significance test. (3) Significant decrease can be recognized in the southerly annual means in the upper tropospheric levels, i.e., between $300 \mathrm{hPa}$ and $500 \mathrm{hPa}$ levels, the fitted linear regression coefficients are $-0.056 \mathrm{~m} / \mathrm{s} /$ year $(300 \mathrm{hPa}$ level), $-0.060 \mathrm{~m} / \mathrm{s} /$ year $(350 \mathrm{hPa}$ level), -0.051 $\mathrm{m} / \mathrm{s} /$ year $(400 \mathrm{hPa}$ level), $-0.036 \mathrm{~m} / \mathrm{s} /$ year $(450 \mathrm{hPa}$ level), $-0.036 \mathrm{~m} / \mathrm{s} /$ year $(500$ $\mathrm{hPa}$ level), with the corresponding p-values from Mann-Kendall test of 0.045, $0.027,0.048,0.043,0.048$, respectively. (4) Westerly mean winds significantly increase at three very high stratospheric levels $(1 \mathrm{hPa}, 2 \mathrm{hPa}, 3 \mathrm{hPa}$ with the trend coefficients of $0.249 \mathrm{~m} / \mathrm{s} /$ year, $0.215 \mathrm{~m} / \mathrm{s} /$ year and $0.164 \mathrm{~m} / \mathrm{s} /$ year, and the corresponding p-values of $0.001,0.009$ and 0.012 , respectively). The fitted trend coefficients become negative below the $20 \mathrm{hPa}$ level, and the identified decrease is significant at the tropospheric levels of $350 \mathrm{hPa}, 400 \mathrm{hPa}, 450 \mathrm{hPa}$, and $500 \mathrm{hPa}$.

In the case of the annual frequency of extreme wind speeds (above $30 \mathrm{~m} / \mathrm{s}$ ), the fitted linear trend coefficients are mostly negative, however, they are not statistically significant in any given direction at any level. The occurrences of strong wind in the easterly, southerly, and northerly direction classes are quite rare at every analyzed level - the average annual frequencies are 3.7 (class E), 2.5 (class S), and 7.3 (class $\mathrm{N}$ ) cases per year considering all the examined levels, whereas strong wind occurred 54.0 cases/year on average in class W.

Finally, the spatial differences of the above discussed linear trends are analyzed. For this purpose, we calculated the linear trend coefficients in every grid point along the longitude of $28.75^{\circ} \mathrm{E}$. The results for the frequency of extreme winds above $30 \mathrm{~m} / \mathrm{s}$ at the $250 \mathrm{hPa}$ level are shown in Fig. 17 for the second part of the period (1997-2015). The trend coefficients show southward increasing negative values, which become significant at the closest latitude to Budapest $\left(47.25^{\circ} \mathrm{N}\right)$. 


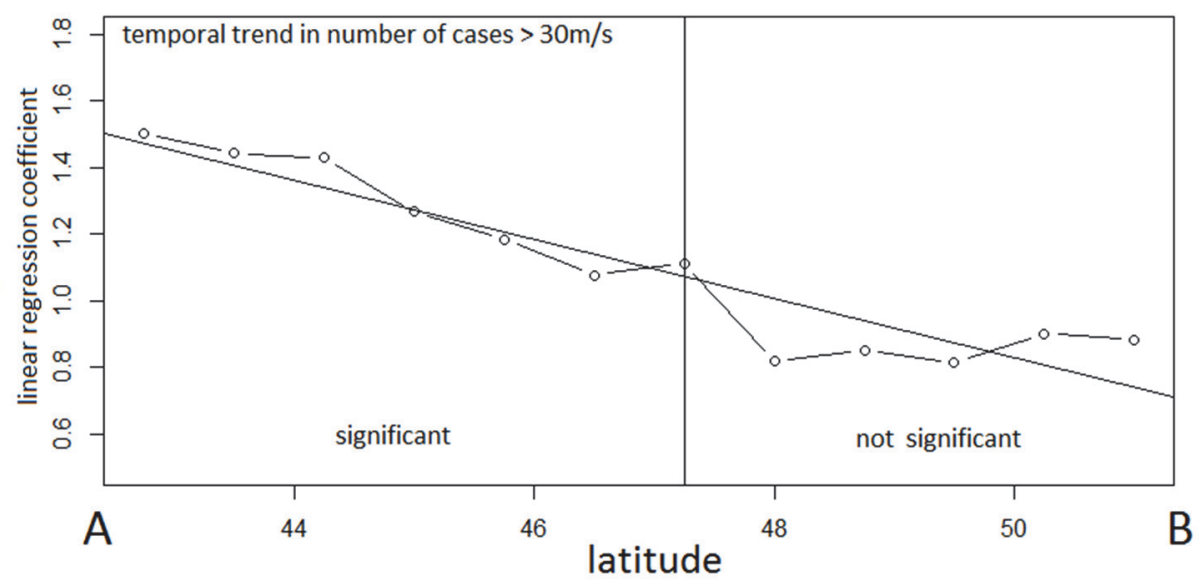

Fig. 17. The absolute value of the linear regression coefficients along the $18.75^{\circ} \mathrm{E}$ longitude (1997-2015) at the $250 \mathrm{hPa}$ level for the frequency of strong wind (i.e., wind speed above $30 \mathrm{~m} / \mathrm{s}$ ).

\section{Conclusions}

From the synoptic meteorological practical experiences we know, that the jet stream has an important effect on daily weather in the midlatitudes. The international literature pays more and more attention to the changes in circulation regimes including jet stream at the midlatitudes (e.g., Francis et al., 2009), as a result of substantial ice melting at the poles due to the detected and expected global warming. In this paper, we analyzed these changes from the specific point of view of the Carpathian Basin. For this purpose, first a general statistical climatological description of the high level wind characteristics was presented using reanalysis data (wind speed and direction) at 22 levels above the $500 \mathrm{hPa}$ level pointing out the general dominance of westerly winds and highlighting the strongest winds at the $250 \mathrm{hPa}$ and $300 \mathrm{hPa}$ levels, which can be considered the vertical position of polar jet stream. Furthermore, we analyzed the temporal behavior of the time series by fitting linear trends on the data. In general, decreases of mean wind speed were found at the tropospheric levels (above $500 \mathrm{hPa}$ ), and increases at the very high stratospheric levels, which do not depend on the direction. Statistically significant trends mostly occurred in westerly winds, which is the most frequent wind direction of the Carpathian region as well, as the midlatitudes in general.

Acknowledgement: Research leading to this paper has been supported by the following sources: the Hungarian National Research, Development and Innovation Fund under grants K-120605 and K129162, the Széchenyi 2020 programme, the European Regional Development Fund and the Hungarian Government (GINOP-2.3.2-15-2016-00028), the Hungarian Ministry of Human Capacities under the ELTE Excellence Program (783-3/2018/FEKUTSRAT). The research was also supported by the Bolyai Research Fellowship of the Hungarian Academy of Sciences. We thank to Csaba Károssy for preparing and providing the Péczely code catalogue. 


\section{References}

Barnes, E.A. and Screen, J.A, 2015: The impact of Arctic warming on the midlatitude jet-stream: Can it? Has it? Will it? WIREs Clim Change 6, 277-286. https://doi.org/10.1002/wcc.337

Barnes, E.A. and Polvani, L., 2013: Response of the midlatitude jets, and of their variability, to increased greenhouse gases in the CMIP5 models. J. Climate, 26, 7117-7135. https://doi.org/10.1175/JCLI-D-12-00536.1

Dee, D.P., Uppala, S.M., Simmons, A.J., Berrisford, P., Poli, P., Kobayashi, S., Andrae, U., Balmaseda, M. A., Balsamo, G., Bauer, P., Bechtold, P., Beljaars, A. C. M., van de Berg, L., Bidlot, J., Bormann, N., Delsol, C., Dragani, R., Fuentes, M., Geer, A. J., Haimberger, L., Healy, S.B., Hersbach, H., Hólm, E. V., Isaksen, L., Kållberg, P., Köhler, M., Matricardi, M., McNally, A.P., Monge-Sanz, B. M., Morcrette, J.-J., Park, B.-K., Peubey, C., de Rosnay, P., Tavolato, C., Thépaut, J.-N., and Vitart, F., 2011 For the case study we used the Péczely synoptic classification types (Péczely, 1983), which has been provided by Cs. Károssy (pers.comm.).: The ERA-Interim reanalysis: configuration and performance of the data assimilation system. Q.J.R. Meteorol. Soc., 137, 553-597. https://doi.org/10.1002/qj.828

Francis, J., and Skific, N., 2015: Evidence linking rapid Arctic warming to mid-latitude weather patterns. Phil.Trans.R. Soc. A. 373: 20140170. https://doi.org/10.1098/rsta.2014.0170

Francis, J.A. and Vavrus, S.J., 2012: Evidence linking Arctic amplification to extreme weather in midlatitudes. Geophys. Res.Letters 39, L06801. https://doi.org/10.1029/2012GL051000

Francis, J.A., Chan, W., Leathers, D.J., Miller, J.R., and Veron, D.E., 2009: Winter Northern Hemisphere weather patterns remember summer Arctic sea-ice extent. Geophys. Res.Lett. 36, L07503. https://doi.org/10.1029/2009GL037274

Grange, S.K., 2014: Technical note: Averaging wind speeds and directions. Technical report. University of Auckland, New Zealand. 12p.

Hwang, Y.T., Frierson, D.M.W., and Kay, J.E., 2011: Coupling between Arctic feedbacks and changes in poleward energy transport. Geophys. Res. Lett. 38, L17704. https://doi.org/10.1029/2011GL048546

Knudsen, E.M., Orsolini, Y.J., Furevik, T., and Hodges, K.I., 2015: Observed anomalous atmospheric patterns in summers of unusual Arctic sea ice melt. J. Geophys. Res. Atmospheres 120, 2595 2611. https://doi.org/10.1002/2014JD022608

Miller, G.H., Alley, R.B., Brigham-Grette, J., Fitzpatrick, J.J., Polyak, L., Serreze, M.C., and White, J.W.C., 2010: Arctic amplification: Can the past constrain the future? Quat. Sci. Rev.29, 17791790. https://doi.org/10.1016/j.quascirev.2010.02.008

Overland, J.E., Francis, J.A., Hanna, E., and Wang, M., 2012: The recent shift in early summer Arctic atmospheric circulation. Geophys. Res. Lett. 39, 1-6. https://doi.org/10.1029/2012GL053268

Péczely, Gy., 1961: The climatological characterisation of the macrosynoptic situations in Hungary. (in Hungarian) Magyarország makroszinoptikus helyzeteinek éghajlati jellemzése. OMSz Kisebb Kiadványai 32. Országos Meteorológiai Szolgálat, Budapest. (In hungarian)

Peings, $Y$. and Magnusdottir, G., 2014: Response of the wintertime northern hemisphere atmospheric circulation to current and projected arctic sea ice decline: A numerical study with CAM5. $J$. Climate 27, 244-264. https://doi.org/10.1175/JCLI-D-13-00272.1

Péliné N.Cs., Bartholy J., Pongrácz R., and Radics K., 2016: Analysis of climate change influences on the wind characteristics in Hungary. Időjárás 120, 53-71.

Screen, J.A. and Simmonds, I., 2010: The central role of diminishing sea ice in recent Arctic temperature amplification. Nature 464, 1334-1337. https://doi.org/10.1038/nature09051

Screen, J.A., and Simmonds, I., 2013: Exploring links between Arctic amplification and mid-latitude weather. Geophys. Res. Lett. 40, 959-964. https://doi.org/10.1002/grl.50174

Vince, E., 2013: Weather of winter 2012/2013. A 2012/13-as tél időjárása. Légkör 58, 40-42. (in Hungarian)

Zhang, $X$., Lu, C. and Guan, Z., 2012: Weakened cyclones, intensified anticyclones and recent extreme cold winter weather events in Eurasia. Environ. Res. Lett, 7, 44044-44051.

https://doi.org/10.1088/1748-9326/7/4/044044 